\title{
Applicability of Herbert Blumer's Symbolic Interactionism to Political Analysis of Internet Communications
}

\section{Применимость символического интеракционизма Герберта Блумера в политическом анализе интернет-коммуникаций}

UDC (УДК) 32.019 .51

Received: 10.02.2020
DOI: $10.12737 / 2587-6295-2020-3-13$

Approved: 21.02.2020 Published: 25.03.2020

Fedorchenko S.N.

Candidate of Political Science, Associate Professor, Professor, Department of Political Science and Law, Deputy Dean of the Faculty of History, Political Science and Law for Research and International Relations, Moscow State Regional University

e-mail: sn.fedorchenko@mgou.ru

Федорченко С.Н.

Канд. полит. наук, доцент, профессор кафедры политологии и права; заместитель декана факультета истории, политологии и права по научной работе и международным отношениям Московского государственного областного университета

e-mail: sn.fedorchenko@mgou.ru

Fedorchenko L.V.

Candidate of Political Science

e-mail: kascandra@mail.ru

Федорченко Л.В.

Канд. полит. наук

e-mail: kascandra@mail.ru

Karlyavina E.V.

Senior Lecturer, Department of International Relations and Geopolicy of Transport, Russian University of Transport MIIT

e-mail: katerinakarlj@yandex.ru

\section{Карлявина Е.В.}

Старший преподаватель кафедры международных отношений и геополитики транспорта Российского университета транспорта (МИИТ)

e-mail: katerinakarlj@yandex.ru

\begin{abstract}
The aim of the article is to study the model of symbolic interactionism by the American sociologist Herbert Blumer and to identify the analytical elements that are most applicable to the political analysis of internet communications. The authors used the hermeneutic approach, including the identification of central premises in Blumer's model as well as an additional interpretation of such premises. Quantitative content analysis was used as an auxiliary methodological optics. The analysis demonstrated that the analytical tools of symbolic interactionism from the Chicago School (definitive and sensitizing concepts, exploration and inspection, etc.) can be effectively tailored
\end{abstract}


and used for current research of internet communications in applied political science. The authors conclude that identifying the transaction process is the most important result of applying Blumer's symbolic interactionism model to a study of social media communities by a political scientist. It is demonstrated that the conditions of social media require investigating the mechanism of behavior adaptation by each individual to the behavior of others. This gives an insight into the mechanism by which social life and the political regime are streamlined and stabilized.

Keywords: Herbert Blumer, symbolic interactionism, internet, social media, political analysis, internet communications, political regime, digitalization.

\begin{abstract}
Аннотация
Целью статьи является выявление аналитических элементов модели символического интеракционизма американского социолога Герберта Блумера, наиболее применимых для политического исследования интернет-коммуникаций. Авторы использовали герменевтический метод, который включал выявление центральных тезисов модели Блумера, а также дополнительную их интерпретацию. В качестве вспомогательной методологической оптики послужил количественный контент-анализ. Результаты анализа показали, что аналитический инструментарий Чикагской школы символического интеракционизма (дефинитивное и сенсибилизирующее понятие, разведка и инспекция и др.) можно хорошо адаптировать для современного исследования сетевых интернеткоммуникаций в прикладной политологии. Делается вывод, что выявление процесса транзакции - это самое важное, что дает модель символического интеракционизма Блумера при исследовании политологом сообществ социальных сетей. Показано, что в условиях социальных сетей необходимо изучать механизм приспособления линий поведения каждого индивида к линиям поведения других индивидов. Это даст понимание основы механизма упорядочивания и стабилизации социальной жизни и политического режима.

Ключевые слова: Герберт Блумер, символический интеракционизм, Интернет, социальные сети, политический анализ, интернет-коммуникации, политический режим, цифровизация.
\end{abstract}

\title{
Introduction
}

The American sociologist Herbert Blumer has published a number of scientific papers that are still awaiting reinterpretation by the academic political science community. The premise that the construction of social reality is an ongoing process is of fundamental importance. This actualization of the social interaction mechanism makes the modern political scientist pay close attention to Blumer's model for understanding the processes taking place on the internet. Blumer's symbolic interactionism model is based on three main points:

a) All people act in relation to objects based on their existing meanings;

b) The meanings of objects are formed based on the social interaction between people;

c) The meanings are used and transformed during the interpretation process [3].

On the one hand, these three premises were proposed by American scientists before the spread of internet social media platforms and were intended to study real social processes. On the other hand, the development of social media promotes their use for analyzing virtual reality and its specific internet communications. Sociologists use several key terms that must be clarified. For example, if "definition" for Blumer is a collective process of instructing another individual on how to act and respond, then "interpretation" is a personal process of interpreting instructions from other individuals [2]. According to Blumer, common definitive and interpretative templates form a "transaction" mechanism for adapting the behavior of each individual to the behavior of others.

Unfortunately, modern political scientists and sociologists often fail to notice the obvious usefulness of Blumer's theoretical and methodological model for studying virtual reality phenomena. Thus, the aim of the article is to consider Blumer's symbolic interactionism model and to identify the analytical elements that are most applicable to the political analysis of internet communications. 


\section{Scientific literature review}

The legacy of the American sociologist Herbert Blumer has been viewed as controversial by researchers. The reason is clear since the American sociologist in many respects reworked the earlier ideas of George Mead and was also part of the Chicago School of symbolic interactionism founded by him, whose representatives paid more attention to new and creative interaction aspects. Meanwhile, the Iowa School of symbolic interactionism (Manford Kuhn and Carl Couch, University of Iowa) focused on exploring the coherence between interactions. The Iowa School used cybernetic and positivist principles, preferring to study small groups in the laboratory to define the behavior patterns of actors and create a clear terminological apparatus for understanding social phenomena. Unlike Herbert Blumer, Manford Kuhn relied on quantitative methods. The Indiana School of symbolic interactionism (Sheldon Stryker, University of Indiana) began studying the most stable symbolic templates that construct and reproduce social structures [4]. Stryker accepted that the premises of symbolic interactionism can be verified using both quantitative and qualitative scientific methods.

Robert Prus believes that the Chicago School is the most consistent successor to the scientific traditions of symbolic interactionism. Its main features are as follows: pragmatism as a focus on active interactions and the procedural mechanism of social communities, production of terms, and ethnographic study of the everyday experience of social groups [8]. An analysis of ethnopolitical processes and phenomena in popular communities on the largest social media platforms is becoming acutely relevant for law enforcement agencies. They could be helped by political scientists working on interdisciplinary projects. Meanwhile, the ideas of the Indiana School can be considered as a certain compromise between the Chicago and Iowa schools; they are quite interesting in terms of studying the legitimacy and stability of political regimes in the modern digital era.

David A. Snow considers Blumer's three main methodological principles underdeveloped and nonspecific since his focus on the problem of interpretation does not apply to researching a range of social phenomena. Based on his experience in analyzing social movements, Snow suggests using the following four principles to develop a theoretical framework of symbolic interactionism instead of the three principles by Blumer: symbolization, interactive determination, human agency, and emergence [9]. But Snow also clarifies that his approach does not contradict Blumer's basic ideas. According to R. J. Maratea and David Keys, Blumer's symbolic interactionism was an innovative approach to social research and went far beyond the temporal and spacial limitations that the French scientist Gustave LeBon, who studied the psychology of the masses, previously had discovered [5]. Blumer managed to shift the focus of social sciences from structural to interactive and behavioral explanations for social phenomena.

Some authors note that Bloomer criticized the mechanistic aspects of the social sciences that treat causative explanations and the use of variables as dogma. Indeed, Blumer even criticized the scientific research technique adopted by the academic community: hyperbolization of procedural descriptions, the existing operationalization method, the dominance of quantitative methods, and the ever-present variables [3]. R. Azarian believes that the main drawback of Blumer's symbolic interactionism model is a lack of concretization of the defining actions by social relations participants. The transactions described by Blumer - that is, practices that people use to coordinate their actions with other members of society, lack clarity. The American sociologist also does not explain the social forces that unite people in any activity and compel them to coordinate their behavior. There is virtually no discussion of the mechanism used by individuals to define and approve the meanings of various objects [1]. The ambiguity leads to difficulties in trying to integrate the theoretical concepts of symbolic interactionism with empirical experience. Meanwhile, Azarian emphasizes that, despite its shortcomings, Blumer's symbolic interactionism is a sound theoretical model with significant potential for an objective analysis of subtle mechanisms of modern political power. Moreover, Roberto Venturini notes that Blumer gradually improved and refined his views in his later works [10], coming back from epistemological 
premises to recognizing the need for procedures in scientific research. Indeed, in his main scientific work called Symbolic Interactionism. Perspective and Method, Blumer criticized the use of detailed procedures for conducting scientific research, but it is not always noted that he proposed his own procedures in the same book ("exploration" and "inspection"). This compels us to reconsider the significance of symbolic interactionism and try to adapt its theoretical and methodological toolset for modern political analysis. This is especially important in the context of digitalization when people interact in communities on social media.

\section{Methods}

First, the hermeneutic approach was used to adapt Blumer's symbolic interactionism models to the political analysis of modern internet communications. According to the German scientist W. J. Patzelt, the hermeneutic approach is one of the most important methods in modern academic political science. The hermeneutic approach is used to understand a scientist's assertion, reconceptualize a research model, and adapt its premises and analytical elements to the present day [7]. Patzelt believes that the hermeneutic approach is best used in two stages: 1) it is important to obtain a preliminary meaning by defining the "central utterance" (the scientist's main premise); 2) additional interpretation of the identified premise and new information will be required to refine the gained knowledge. Both stages of the analytical procedure are repeated until a political scientist is able to gain a deep understanding of the controversial premise(s). Patzelt compares the two stages of the hermeneutic approach with Archimedes' "movement of the screw" that gradually draws closer to the essence of the considered problem. It is notable that Patzelt advises using several hermeneutic approach techniques to solve complex problems:

a) Let it pass (the theory's unclear elements, premises, and terms are temporarily set aside until more information is obtained for their full understanding);

b) Filling in (it is accepted that obscure theoretical elements, the author's terms and ideas may also contain temporarily inaccessible meaning for the modern scientist);

c) Unless (due to the lack of a better explanation for a theoretical premise or element, scientists use the operational explanation that is currently proposed);

d) Retrospective and prospective interpretation (the old meanings of the theoretical elements, terms, and premises are rethought and reinterpreted if new data appear);

e) Constructing interpretative templates (based on analyzing consistent patterns after performing hermeneutic procedures);

f) Interpretation of exceptions and deviations.

The Twitter community of the US President Donald Trump was chosen at the next stage to test the applicability of Blumer's symbolic interactionism model to the political analysis of internet communications. Additional methodological optics of quantitative content analysis were employed for this purpose:

a) The statistical web resource socialblade.com was used to check the relationship between the growth in the number of posts (tweets) and increase in the number of the subscribers;

b) The statistical web resource tweetstats.com helped identify the most frequently used Twitter community hashtags (hashtags (\#) make it easier to search for information by keywords and are also hyperlinks and political messages). This resource also provided information on Trump's community reactions to other accounts. Thus, the content analysis units were the number of subscribers, tweets, and hashtags in Trump's community. 


\section{Results}

The hermeneutic analysis made it possible to: a) identify the central meaning of Blumer's symbolic interactionism model elements; b) tailor the identified elements to the political analysis of modern internet communications. All results were summarized in a table for convenience.

Table

Adapting Herbert Blumer's model to the political analysis of internet communications

\begin{tabular}{|c|c|c|}
\hline $\begin{array}{c}\text { Model } \\
\text { elements }\end{array}$ & Meaning of the elements & Adaptation \\
\hline Definitive concept & $\begin{array}{l}\text { The type of scientific term that clearly } \\
\text { defines a political phenomenon and } \\
\text { allows one to analyze its static features } \\
\text { (power, state, subject of management, } \\
\text { object of management, network } \\
\text { community, echo chamber, political } \\
\text { agenda, political discourse, artificial } \\
\text { intelligence, hashtags, etc.). }\end{array}$ & $\begin{array}{l}\text { It enables an analysis of } \\
\text { the same political } \\
\text { phenomena in real and } \\
\text { virtual realms, comparing } \\
\text { their features and } \\
\text { identifying common } \\
\text { patterns from the political } \\
\text { science viewpoint. }\end{array}$ \\
\hline Sensitizing concept & $\begin{array}{l}\text { A type of scientific term that does not } \\
\text { clearly explain a poorly studied political } \\
\text { phenomenon but only outlines areas for } \\
\text { future detailed study (meme, archetype, } \\
\text { fakes, digitalization, digital sovereignty, } \\
\text { digital detox, etc.). }\end{array}$ & $\begin{array}{l}\text { It helps analyze poorly } \\
\text { investigated political } \\
\text { phenomena in real and } \\
\text { virtual realms with the } \\
\text { aim of detailing and } \\
\text { transforming them into a } \\
\text { more specific definitive } \\
\text { concept. }\end{array}$ \\
\hline Exploration & $\begin{array}{l}\text { A flexible research procedure that allows } \\
\text { a scientist to switch from one search } \\
\text { direction to another until the most } \\
\text { comprehensive explanation of social life } \\
\text { is obtained. }\end{array}$ & $\begin{array}{l}\text { Exploration should be } \\
\text { used to analyze new } \\
\text { analytical communication } \\
\text { elements such as social } \\
\text { media, the internet of } \\
\text { things, artificial } \\
\text { intelligence, hologram, } \\
\text { cloud computing, } \\
\text { multiplayer computer } \\
\text { games, chatbots, machine } \\
\text { vision, and spam bots. }\end{array}$ \\
\hline Inspection & $\begin{array}{l}\text { An intensive procedure for studying the } \\
\text { empirical aspects of analytical elements } \\
\text { and the empirical content of the } \\
\text { relationships between these elements. It } \\
\text { involves an in-depth analysis of political } \\
\text { phenomena identified by the exploration } \\
\text { procedure using various scientific } \\
\text { methods. }\end{array}$ & $\begin{array}{l}\text { For example, the political } \\
\text { discourse in social media } \\
\text { communities can be } \\
\text { studied using quantitative } \\
\text { content analysis and } \\
\text { additional SWOT } \\
\text { analysis of } \\
\text { communication effects. }\end{array}$ \\
\hline Meanings & $\begin{array}{l}\text { Meanings are social products created } \\
\text { during social interaction. Meanings can } \\
\text { be assigned to political symbols, coats of } \\
\text { arms (of countries, ministries and cities), } \\
\text { archetypes, memes, metaphors, } \\
\text { stereotypes, consistent behavior patterns, } \\
\text { political party brands, political }\end{array}$ & $\begin{array}{l}\text { It will also be useful to } \\
\text { study the specifics of } \\
\text { representations and the } \\
\text { processes of distorting } \\
\text { initial meanings in } \\
\text { internet communications. }\end{array}$ \\
\hline
\end{tabular}




\begin{tabular}{|c|c|c|}
\hline $\begin{array}{c}\text { Model } \\
\text { elements }\end{array}$ & Meaning of the elements & Adaptation \\
\hline & $\begin{array}{l}\text { statements, messages, image, slogans, } \\
\text { phrases and entire speeches of political } \\
\text { leaders, etc. }\end{array}$ & \\
\hline Interpretation & $\begin{array}{l}\text { Interpretation is a personal process of } \\
\text { interpreting the instructions of other } \\
\text { individuals, including the meanings of } \\
\text { their words or actions. It is guided by } \\
\text { stimuli, prompts, and definitions of } \\
\text { meanings coming mainly from reference } \\
\text { groups. This intermediate process occurs } \\
\text { between the communication and its after- } \\
\text { effect. }\end{array}$ & $\begin{array}{l}\text { Different interpretations } \\
\text { of the same political } \\
\text { meanings can be studied } \\
\text { in a comparative analysis } \\
\text { of various social media } \\
\text { communities. }\end{array}$ \\
\hline Definition & $\begin{array}{l}\text { This is a collective process of } \\
\text { communicating to another individual } \\
\text { instructions on how to act and respond. } \\
\text { Socialization becomes the cultivation of } \\
\text { an ability to successfully take on other } \\
\text { individuals' roles. Social control turns } \\
\text { into self-control as a result. }\end{array}$ & $\begin{array}{l}\text { The dominant political } \\
\text { definition schemes can be } \\
\text { studied on the example of } \\
\text { the echo chamber effect } \\
\text { in social media } \\
\text { communities. }\end{array}$ \\
\hline Transaction & $\begin{array}{l}\text { Transaction involves adapting the actions } \\
\text { and behavior of each individual to the } \\
\text { actions and behavior of others as the basis } \\
\text { for ordering and stabilizing group life. A } \\
\text { transaction is actually a dual process of } \\
\text { interpretation and definition. The } \\
\text { established group life templates are based } \\
\text { on the continuity of interpretative and } \\
\text { definitive schemes. }\end{array}$ & $\begin{array}{l}\text { Continuity as an integral } \\
\text { part of a transaction can } \\
\text { be analyzed in terms of } \\
\text { established political } \\
\text { values in social media } \\
\text { communities. }\end{array}$ \\
\hline Network & $\begin{array}{l}\text { A network is the linking and } \\
\text { interdependence of various actions by } \\
\text { different individuals that possess a set of } \\
\text { meanings and interpretations and create } \\
\text { institutions. Even when faced with totally } \\
\text { novel situations, individuals develop } \\
\text { forms of joint action based on continuity } \\
\text { with previous collective interaction } \\
\text { patterns and set of meanings. }\end{array}$ & $\begin{array}{l}\text { Such an approach to the } \\
\text { network helps } \\
\text { comprehend its } \\
\text { mechanism and prospects } \\
\text { for the institutionalization } \\
\text { of organized network } \\
\text { structures and } \\
\text { communities that are } \\
\text { based primarily on } \\
\text { "strong" rather than } \\
\text { "weak" ties. }\end{array}$ \\
\hline $\begin{array}{l}\text { Communication } \\
\text { process }\end{array}$ & $\begin{array}{l}\text { It includes the following: } \\
\text { interdependence of forms of } \\
\text { communication; changeability and } \\
\text { variability of presentations in } \\
\text { communication methods; changeability } \\
\text { and variability of people's sensitivity to } \\
\text { communication methods; interpretation } \\
\text { process; immersion in the world of } \\
\text { moving events. }\end{array}$ & $\begin{array}{l}\text { This explanation is well- } \\
\text { correlated with modern } \\
\text { changes in social } \\
\text { media-algorithmic news } \\
\text { feeds take into account } \\
\text { the internet user's reaction } \\
\text { (their likes, comments, } \\
\text { reposts, views of specific } \\
\text { websites, etc.). }\end{array}$ \\
\hline Functional groups & $\begin{array}{l}\text { Social organizations with leaders and } \\
\text { interests endowed with various powers }\end{array}$ & $\begin{array}{l}\text { This leads to rethinking } \\
\text { the phenomenon of }\end{array}$ \\
\hline
\end{tabular}




\begin{tabular}{|l|l|l|}
\hline $\begin{array}{c}\text { Model } \\
\text { elements }\end{array}$ & \multicolumn{1}{|c|}{ Meaning of the elements } & \multicolumn{1}{|c|}{ Adaptation } \\
\hline $\begin{array}{l}\text { and seeking to use communication } \\
\text { channels to influence key individuals } \\
\text { making political decisions. }\end{array}$ & $\begin{array}{l}\text { influence groups in } \\
\text { internet communications. } \\
\text { An example is the role of } \\
\text { social media bots in } \\
\text { shaping the political } \\
\text { agenda in the virtual } \\
\text { environment. }\end{array}$ \\
\hline Public opinion & $\begin{array}{l}\text { Diversified interaction between } \\
\text { functional groups occupying different } \\
\text { strategic positions and individuals rather } \\
\text { than between separate individuals. }\end{array}$ & $\begin{array}{l}\text { Such a perspective } \\
\text { provides a key to } \\
\text { understanding the } \\
\text { mechanism that shapes } \\
\text { the political agenda and } \\
\text { its impact in internet } \\
\text { communications. }\end{array}$ \\
\hline
\end{tabular}

The quantitative content analysis conducted using the socialblade.com website revealed a relationship between the expanding number of tweets in Trump's virtual community and increase in his subscribers (see figures 1,2).

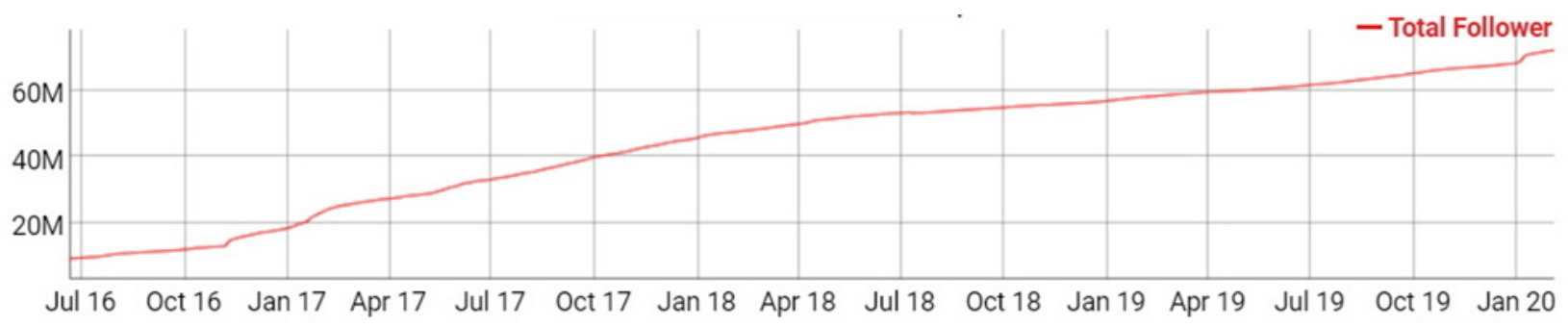

Figure 1. Increase in Trump's community followers ( $\mathrm{M}$ stands for million of followers)

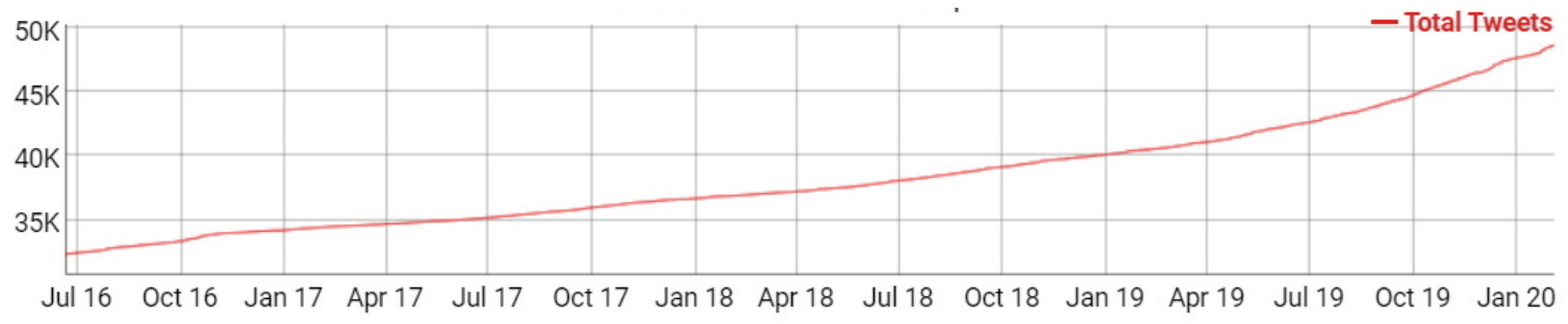

Figure 2. Increase in the number of tweets in Trump's community (K stands for thousand tweets) 


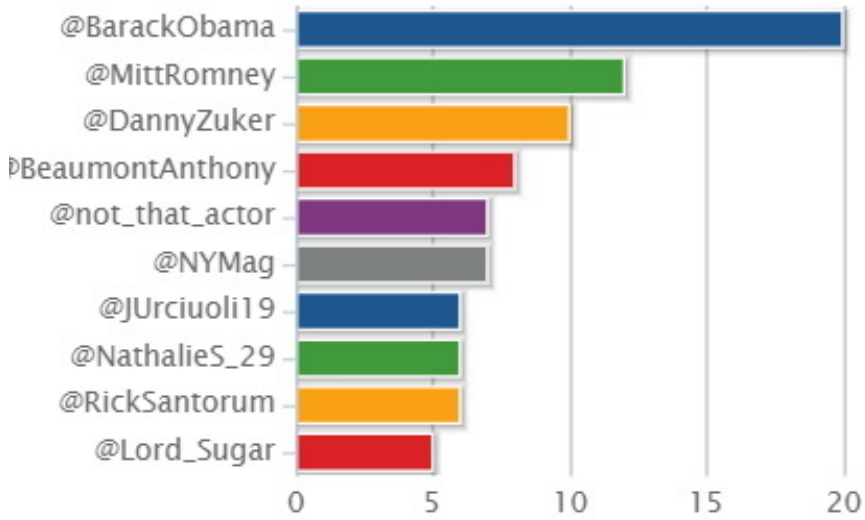

Who You ReTweet (RT's - 15.10\% of total tweets)

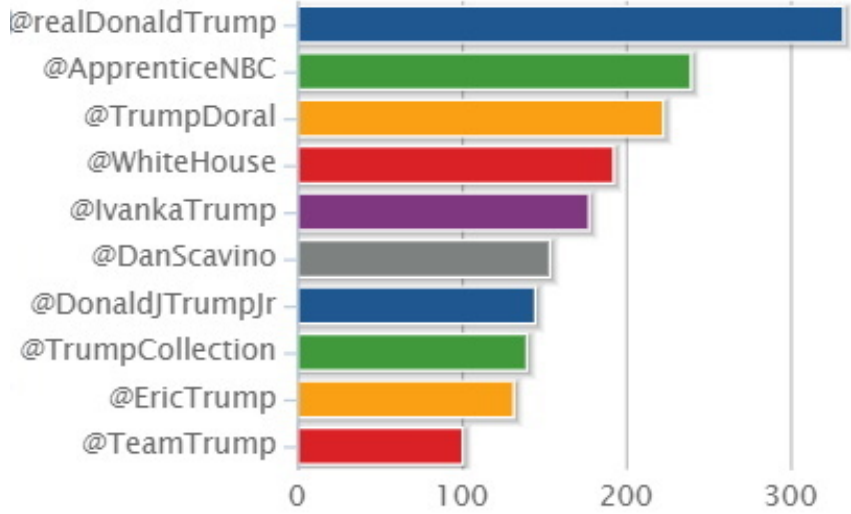

Figure 3. Trump's community reaction to other accounts and his retweets

\begin{abstract}
\#1 \#2 \#2016 \#2a \#alsicebucketchallenge \#america \#americafirst \#asktrump \#bigleaguetruth \#bluemonster \#cadillacchamp \#caucusfortrump \#celebapprentice \#celebapprenticemvp \#celebrityapprentice \#chicago \#cnn \#cnndebate \#cpac2015 \#crippledamerica \#crookedhillary \#debate \#debatenight \#debates \#debates2016 \#demdebate \#donaldtrump \#doral \#dorian \#draintheswamp \#fakenews \#fitn \#followthedonald \#golf \#gop \#gopdebate \#hannity \#hurricaneharvey \#iacaucus \#icebucketchallenge \#icymi \#impeachment. \#imwithyou \#inprimary \#isis \#kag2020 \#lesm \#maga \#maga... \#magaus \#makeamericagreatagain \#missuniverse \#missusa \#nhpolitics \#nyc \#nyprimary \#obama \#obamacare \#oscars \#potus \#ncincle \#snl \#success \#supertuesday \#sweepstweet \#tbt \#tcot \#teamtrump \#thankyoutour2016 \#theapprentice \#theartofthedeal \#timetogettough \#toronto \#transformationtuesday \#traveltuesday \#trump \#trump16 \#trump2016 \#trump4prez \#trumpadvice \#trumpchicago \#trumpdoral \#trumpferrypoint \#trumpforpresident \#trumpgolf \#trumppence16 \#trumprally \#trumptower \#trumptrain \#trumptuesday \#trumpvlog \#usa \#usa us \#usmca \#votetrump \#votetrump2016 \#vpdebate \#wakeupamerica \#wiprimary \#wwehof
\end{abstract}

Figure 4. Popular hashtags in Trump's community

The quantitative content analysis using the tweetstats.com website (figure 3) revealed that Trump's community interacts the most with the community of former US president Barack Obama (the interaction includes contacts between the two accounts and the reaction of the members of virtual communities forming around these accounts). There is also a reaction to the tweets of the Republican politician Mitt Romney and the writer and producer Danny Zucker. Retweets include tweets from their own community as well as from those of NBC, White House, and Trump's relatives and supporters. The most commonly used hashtags in Trump's community (see figure 4) are: \#makeamericagreatagain, \#trump2016, \#celebapprentice, \#maga, \#1. 


\section{Discussion and Conclusions}

So, let us try to interpret the results. The hermeneutic approach helped us clarify the main analytical elements of Blumer's symbolic interactionism that are useful for the political science study of internet communications: definitive concept, sensitizing concept, exploration, inspection, meanings, interpretation, definition, transaction, network, communication process, functional groups, public opinion. Of course, there are other elements, but the elements listed above can be considered the most well-developed by the American sociologist. How can a modern political scientist use these elements of Blumer's model?

First, during the first stage (exploration) of the study based on the Blumer model, a political scientist can clarify the operational terms that they will have to deal with, for example, when analyzing political discourse on social media. Grouping the terms into "definitive" and "sensitizing" is a very useful approach. In many respects, the internet remains an innovative sphere for academic political science; thus, certain generally accepted definitions may not suffice for its interpretation and conceptualization. Meanwhile, the introduction of sensitizing concepts does not violate Occam's razor while broadening the researcher's horizons by providing them with the advantages of an interdisciplinary principle. An example of such a sensitizing concept is the meme. Richard Dawkins considers the meme to be a kind of replicator-that is, a reproducing and disseminating element of cultural information; however, such an interpretation is not always suitable for creating a procedure and conducting empirical research as it is insufficiently studied. Nevertheless, the conditions of virtual reality enable identifying more specific internet memes as a type of dual-layer viral network messages containing semiotically different opinions on current news and issues. Such internet memes are usually packaged in vivid images. A similar sensitizing and largely operational concept is proposed by S. A. Shomova. The quantitative content analysis using socialblade.com that identified a relationship between the expanding number of tweets in Trump's virtual community and increasing number of followers is an example of the research exploration procedure proposed by Blumer.

Inspection as the next research stage may also include a series of empirical measurements of internet memes. At the conclusion of this stage one may proceed to creating a more permanent definitive concept. The quantitative content analysis through tweetstats.com that characterized the interaction between Trump's community and other communities and accounts as well as hashtags can also be viewed as an example of the second research stage using Blumer's model (inspection). It is noteworthy that the meaning of two research stages (exploration and inspection) proposed by Blumer coincides with the two hermeneutic approach stages according to the German scientist W. J. Patzelt.

Identifying the dual "transaction" process is the most important outcome of applying Blumer's symbolic interactionism toolset to studying social media communities in political science. If, for instance, certain network communities are considered as echo chambers, they can illustrate the mechanisms of the two transaction components (interpretation and definition). It is extremely important to understand how the behavior of each individual is tailored to the behavior of others as the basis of ordering and stabilizing social life and the political regime. This is a key issue for modern political power in the context of widespread internet social media, traditional state sovereignty crisis, and declining public trust in traditional political institutions. The majority of technologically advanced political regimes in various countries are interested in maintaining their legitimacy and stability; therefore, they will use increasingly flexible and inconspicuous manipulative technologies to control mass consciousness. The key goal of such technologies is the political regime's control over the most important meanings of such concepts as justice, freedom, equality, value, civil society, politics, effectiveness, democracy, etc. It is strategically important for any political regime to control how such concepts are defined and interpreted.

Blumer's illustration of the network phenomenon can be considered a real breakthrough. His hypothesis helps us evaluate the prospects for the institutionalization of modern network communications which members of the public are taking an increasingly active part in and which are increasingly controlled by large corporations and political regimes. Blumer's concepts of 
interdependence, interweaving, and variability of communications as well as mutual changeability and variability of people's sensitivity to communication media are especially useful for internet analysis since modern social media actually use algorithmic news feeds that take into account the internet user's reaction. An analysis of innovative communication methods would be very useful for researchers. For instance, if holographic chat emerges and becomes affordable, it will to an extent revolutionize interaction between people. Currently, holograms are used only by political leaders to maintain their positive image. Symbolic interactionism can also be used in future studies of human interaction with artificial intelligence through social media platforms. Artificial intelligence could be the future digital community development that will overtake the entire human sociopolitical existence through compatible API algorithms, network communities, egovernments, services, multiplayer games, holograms, the internet of things, machine vision, cloud computing, drones, and Big Data methodological optics. Academic political science needs to pay more attention to these phenomena to assist people in raising media literacy, resisting fakes/manipulations, and preventing a destructive transformation of democratic regimes into authoritarian and totalitarian ones in the conditions of digitalization. Political science in a digital society reflects the political regime's effectiveness.

Blumer's concept of functional groups and their role in structuring public opinion has great potential in the study of social media and communities by political science, despite being underappreciated by researchers. Blumer is sometimes criticized for not analyzing the subjects of political governance within his model, but the functional group concept could not be more suitable for studying the role and place of modern political elites in network communications. Blumer's model will likely benefit if supplemented with conceptual analysis of power by V. G. Ledyayev [6] who studied the technologies of the subject of management toward the object of management in detail. Functional groups fit well into the model of organized networks with strong ties that according to the hypothesis by Dutch theoretician Geert Lovink are capable of displacing modern networks with weak ties used by corporations like Facebook to profit from people. Of course, such a civil collaboration is a priori opposed by the political elite. However, the elite itself is changing with the advent of a network society, trying to stay current and simulate openness for anyone. Other scientist besides Manuel Castells and John Urry have written about network elites. For instance, Geert Lovink believes that transformation of the elite involves delegation of its authority to community administrators, while most users are faced with a lack of time due to the constant need to be online. Nevertheless, no scientist has yet proposed a detailed description of this new elite in a digital society. Symbolic interactionism can provide an impetus for solving this problem and will contribute to the transition of democracy to a new level of interaction between society and the state.

\section{Acknowledgements}

In conclusion, the authors would like to thank Doctor of Political Sciences, Professor of the Lomonosov Moscow State University S.V. Volodenkov. Conversations with him on the problems of modern social media inspired us to write this article.

\section{References}

1. Azarian R., Joint Actions, Stories and Symbolic Structures: A Contribution to Herbert Blumer's Conceptual Framework. Sociology, 2015, V. 51, I. 3, pp. 685-700. DOI: $10.1177 / 0038038515609029$.

2. Baugh Jr.K. The Methodology of Herbert Blumer (American Sociological Association Rose Monographs). Cambridge, Cambridge University Press Publ., 2006, 124 p. DOI: 10.1017/CBO9780511570858.

3. Blumer H. Symbolic Interactionism. Perspective and Method. Berkley, Los Angeles, London, University of California Press Publ., 1986, 224 p. 
4. Carter M.J., Fuller C. Symbolic interactionism: The past, present, and future of symbolic interactionism. Current Sociology, 2016, V. 64, I. 6, pp. 931-961. DOI: 10.1177/0011392116638396.

5. Keys D., Maratea R.J. Life experience and the value-free foundations of Blumer's collective behavior theory. Journal of the History of the Behavioral Sciences, 2011, V. 47, I. 2, pp. 173-186. DOI: 10.1002/jhbs.20494.

6. Ledyaev V.G. Power: A Conceptual Analysis. N.Y., Nova Science Publ., 1998, 246 p.

7. Patzelt W.J. Grundlagen der Ethnomethodologie: Theorie, Empirie und politikwissenschaftlicher Nutzen einer Soziologie des Alltags. München, W. Fink Publ., 1987, 384 p.

8. Prus R. Authenticity, activity, and conceptuality: Generating a pluralist, humanist, and enduring social science. Studies in symbolic interaction. Oxford, Emerald Group Publishing Limited, Bingley Publ., 2008, V. 32, pp. 19-36. DOI: 10.1016/S0163-2396(08)32003-1.

9. Snow D.A. Extending and Broadening Blumer's Conceptualization of Symbolic Interactionism. Symbolic Interaction, 2001. V. 24, I. 3, pp. 367-377. DOI: 10.1525/si.2001.24.3.367.

10. Venturini R. Blumer and the Problem of Concepts in the Social Sciences. The Present and Future of Symbolic Interactionism. Milano, Università di Pisa, Society for the Study of Symbolic Interaction, Associazione italiana di sociologia, FrancoAngeli Publ., 2012, V. 2, pp. 133-149. 